\title{
LAND AND ITS RELATIONSHIP TO POSTCOLONIAL PERSPECTIVES IN AMA ATTA AIDO'S PLAY “ANOWA” AND ARUNDHATI ROY'S NOVEL “THE GOD OF SMALL THINGS"
}

\author{
Hishryar M. Ameen \\ Dept. of Kurdish Language, College of Education -Akre, University of Duhok, Kurdistan Region - Iraq. \\ (Email: hishyar812005@yahoo.com )
}

Received: 04. 2017 / Accepted: 04. 2017 / Published: 06. 2017

https://doi.org/10.26436/2017.5.2.400

\begin{abstract}
This paper discusses the issue of land within the postcolonial perspective. Land has always been a shelter protecting nations from disappearing. In this context, land for the postcolonial people does not only represent a specific area in the globe, but more as a sign of their identity and recognition. The placement and displacement of people from their land means much more than simply leaving to another zone, but it refers to the whole element of identity, culture, language, and existence. This research studies two literary works written by writers from colonialized nations. It aims at exploring the theme of land and the identity by two writers from two different nations; from India and Ghana. The text "The God of Small Things" was written by an Indian writer named Arundhati Roy, while the other text is "Anowa" written by Ama Atta Aidoo. The concept of land was pictured in the works of these two writers as the source of being and existence of the nations.

This paper is divided into several sub topics. First, it gives an introduction. Then it discusses land in the perspective of postcolonial literature. Next, it explains the objectives behind the opening sentences of the two texts. Following this part, the paper shows the importance of land being the identity of nations. Subsequently, land has become the source of being and life. Consequently, it propose homeland as the best place for living of a nation and the importance of one sticking to their home and serving it. Finally, it comes to a conclusion that people should raise their national spirit towards their place of origin and serve it in order to avoid future colonialism campaigns and prevent the consequences.
\end{abstract}

KEYWORDS: Postcolonialism, Place as a postcolonial concept, land as an identity.

\section{INTRODUCTION}

Postcolonial literature mainly refers to the literary production of those writers who came from nations that had been living under the colonization of Britain Empire or broadly to say; nations which had been European colonies and have been "affected by the imperial process from the moment of colonization to the present day" (Ashcroft et al., 1989, P. 2). Basically, a number of people from European countries travelled around the world into Africa, Asia, South America, and not to mention North America. According to Wendy Knepper, the starting point of colonialism dates back to the arrival of Christopher Columbus in America in 1492, until its decline and demise in the twentieth century $(2011$, p. 1$)$. The colonial campaign above all is a means of exploiting and raping the foreign lands of those people in the primitive and undeveloped world. They looted their land and their resources, both natural and human. However, not only did they exploit their lands, but they further manipulate their resources. In addition, they enslave and abuse their people, forcing the displacement of the origin people from their land and substituting them with their own people.

Throughout the colonization period, the tradition and cultures of the colonized people were subjected to foreign tenet, neglecting, suppressed, and was denigrated in favor of praising the tradition and culture of the colonizer. These concepts were clearly stated in Cecil Rhodes, who was a mining magnate and politician migrated to South Africa. Rhodes defended the British imperialism in his 'Confession of Faith' (1877) where he observed "that we [the British] are the first race in the world and that the more of the world we inhabit, the better it is for the human race." (Knepper, 2011, p. 15) Furthermore he continues to "uphold the imperial ideologies of domination and underpinned by a confident faith in Britain's cultural and racial supremacy." (Knepper, 2011, p. 15) Due to the colonizer's cruelty and savageness and due to the raising spirit of nationality and patriotism of the colonized people, liberation campaigns and fights were an ongoing operation of the period. By the beginning of the $20^{\text {th }}$ century, the anti-colonial liberation movement flew out all over the places and people started gaining back their freedom.

Writers from these nations started to write literary pieces after the decolonization and liberation process. After many years of living under the control of Imperial forces, the work of these writers have reflected the effect of colonization on culture, society, mentality of people, and almost all other aspects of life. However, mainly the term "Post-colonialism...deals with the effects of colonization on cultures and societies. As originally used by historians after the Second World War in terms such as the post-colonial state, 'post-colonial' had a clearly chronological meaning, designating the postindependence period. However, from the late 1970s, the term has been used by literary critics to discuss the various cultural effects of colonization." (Ashcroft et al., 1998, p. 186)

The nations who experienced the colonization rule, whether during the time of colonization or in the post- colonization era, had practiced or started to take writing in literature as one of the very active ways to reflect and resist the issues caused bycolonization. The role of literature was not only to free land, but it goes far beyond to build a free thinking and consciousness. Postcolonial literature attempts to counteract the alienation of the original people from their lands, culture, 
and language through description, narration, and dramatization. The postcolonial literature tries to emphasize the importance and validity of their indigenous tradition aimed at regaining the pride which is systematically degraded by the colonizers. As the colonizers are the super power, they try to write history in their favorite. Thus, another important objective of the postcolonial literature is to resist such campaign and rewrite the history from the perspective of those colonized in order to unveil the truth to the new generation.

As it was mentioned above, a great number of writers and thinkers have discussed issues and problems caused by colonialism. On the same course, many novelists and playwrights built up their stories around colonialism and postcolonialism matters. The most important point and the priority of these issues was the freedom of their land. The liberation of their land was the starting point to begin a free life. Therefore, what the writers did was not less valuable and not less important than what the freedom fighters did. The freedom fighters were fighting on the ground to liberate land and people, while the writers' fight was to liberate mind and increase awareness. For the sake of this discussion, two different works, written by two writers, both from colonized nations, will be discussed in terms of the importance of land. A play by a Ghanaian female writer, Ama Ata Aidoo, under the title of Anowa and The God of Small Things (TGST) which is a novel by the Indian female writer, Arundhati Roy, were the focus of this paper.

\section{PLACE IN THE PERSPECTIVE OF POSTCOLONIAL LITERATURE}

The concept of place and displacement is one of the most familiar aspects of literature which is produced by writers from former colonized nations. It is a clear observation that the colonial campaign was aimed at occupying and exploiting the territories and lands. However, that notion of place and location are the center of the writings of postcolonial writings. Before the emergence of colonization operations, land was not a figure which could lead to struggle. The sense of "place may be embedded in cultural history, in legend and language, without becoming a concept of contention and struggle until the profound discursive interference of colonialism." (Ashcroft et al., 1998, P. 177) Here, the issue of place and displacement does not only refer to a land settled, but it "demonstrate[s] the very complex interaction of language, history, and environment in the experience of colonized people and the importance of space and location in the process of identity formation" (Ashcroft et al., 1998, P. 177)

The colonization of others such as land, displacement, and migration of people raise complex issues for the colonized nation. Thus, such an intervention and occupation could lead to the dissolving of a whole nation and "it is here that the special post-colonial crisis of identity comes into being; the concern with the development or recovery of an effective identifying relationship between self and place." (Ashcroft and et al 1989, P. 8) Furthermore, in addition to the relationship between preserving a nation's identity and place, the issue of displacement could refer to both geographical and mental alienation from the land of origin. It demonstrates the physical displacement which results in very dangerous aftermaths such as creating a sense of mentally, culturally, and being socially deprived from their place. It is due to such important and crucial issues the term has commanded growing interests with the critics and writers of postcolonial literature. The concerns about place have become a major feature with the postcolonial literature. "The dialectic of place and displacement is always a feature of postcolonial societies whether these have been created by a process of settlement, intervention, or a mixture of the two." (Ashcroft et al., 1989, P. 9)

\section{THE OPENING OF THE TWO TEXTS}

To begin looking at Aido's Anowa and Roy's TGST, it is important to pause for a moment and have a look at the opening of the two texts. Both writers begin with describing a place, whether this place is a real place of their own homeland or it is a symbolic fictional place representing the theme of homeland in general. Roy has set her novel in the small village of Ayemenem in Kerala and this is the same village where she was raised up. Here, she starts describing the place in the first opening paragraph as she says, "May in Ayemenem is a hot, brooding month. The days are long and humid. The river shrinks and black crows gorge on bright mangoes in still, dust green trees. Red bananas ripen. Jackfruits burst. Dissolute bluebottles hum vacuously in the fruity air. Then they stun themselves against clear windowpanes and die, fatly baffled in the sun." (Roy, 1997, p.1)

The village of Ayemenem is described before anything else and it is an unbearably abundant and is full of life and energy, "The nights are clear, but suffused with sloth and sullen expectation. But by early June, the southwest monsoon breaks and there are three months of wind and water with short spells of sharp, glittering sunshine that thrilled children snatch to play with. The countryside turns an immodest green. Boundaries blur as tapioca fences take root and bloom. Brick walls turn moss green. Pepper vines snake up electric poles. Wild creepers burst through laterite banks and spill across flooded roads. Boats ply in the bazaars. And small fish appear in the puddles that fill the PWD potholes on the highways." (Roy, 1997, p.1) All of a sudden, the weather turns rainy, gloomy, and sad with the arrival of Rahel as a sign of human's destruction to nature and good places, "It was raining when Rahel came back to Ayemenem. Slanting silver ropes slammed into loose earth, plowing it up like gunfire. The old house on the hill wore its steep, gabled roof pulled over its ears like a low hat. The walls, streaked with moss, had grown soft, and bulged a little with dampness that seeped up from the ground." (Roy, 1997, p.1)

The aim behind such a beginning is to emphasize both technical and thematic importance of place in her writings. Such an opening of the story reflects the value of land in the texts. Specifically, when it comes to Roy's practical life, precious description of a homeland in her writing as a fictional piece were accompanied by her real life cherishing of her homeland. For Roy, before going into the fictional life, her time is, "taken up as she has ... battles in progress, supporting the oppressed poor classes in their struggle for their land threatened by the dam projects...." (Balvannanadhan, 2007, p. 15) Her real life experiences indicate how she is committed to the homeland and its people through defending and supporting the right of poor people in preserving their land. Furthermore, she was also standing against the Indian government dam project which was meant to perish the agricultural life of the poor. This example demonstrates her practical roles and activities on the ground.

Aidoo drags the curtain of her play Anowa by a speech of the Old man (one of the characters in the play). The Old man directly starts describing the state of Abura, the setting city of 
the play, as he says, "here in the state of Abura, which must surely be one of the best pieces of land, Odomankoma, our creator, has given to man, everything happens in moderation." (Aidoo, 1987, p. 65) The original land that belongs to the people is portrayed as a pleasant and fruitful place where even when, "the sun comes out each day, but its heat seldom burns our corpse; Rains are good when they fall, and Asaase Efua the earth-goddess gives herself, to them that know all the seasons; Stream abound, which like all gods, must have their angry moments as well, but floods hardly known to a living memory." (Aidoo, 1987, p. 65) Furthermore, the Old man describes the mountain Aburabura as a beautiful maiden, where she sits, "with her neck to the skies" (Aidoo, 1987, p. $65)$ and as a teacher reminding people that the earth is a globe shape and not flat. The Old man continues to present the beauty and productivity of their land as even the wide deep ocean is very friendly and calm with its people as he states that, "[h]is day must be sacred. We know him well and even the most unadventurous can reap his fish, just sitting on his pretty sands" (Aidoo, 1987, p. 65) Both writers describe the place in a nice, abundant and alive picture, where it shows that people are very attached to their land. Thus, it plays a very important role in their life as colonized nations or even after independence.

\section{LAND IS THE IDENTITY OF THE NATIONS}

For post-colonial writers, a place is more than just a populated piece of land. Defending the homeland is not only about stating safe, but it is all about freedom and breaking the change of slavery. This is because under colonization, people cannot think to see the whole picture as Chacko (one of the characters) explains that when, "we look in through the windows, all we see are shadows. And when we try and listen, all we hear is a whispering. And we cannot understand the whispering, because our minds have been invaded by a war. A war that we have won and lost. The very worst sort of war. A war that captures dreams and re-dreams them. A war that has made us adore our conquerors and despise ourselves." (Roy, 2007, p. 27)

Subsequently, Bill Ashcroft, Gareth Griffiths and Helen Tiffin (1998, p. 181) describes the importance of land in postcolonial writings in their book Key Concept in Post-Colonial Studies as that, "[w]hat becomes apparent in these writers is that 'place' is much more than the land. The theory of place does not propose a simple separation between the 'place' named and described in language, and some 'real' place inaccessible to it, but rather indicates that in some sense, place is language, something in constant flux, a discourse in process." Also from the opening speech of Anowa, an impression of anticolonization is given that constitutes the native settlers as the only righteous people to live on their land because, "Odomankoma, our creator, has given to man." (Aidoo, 2004, P. 65)

Therefore, this indicates the right of original people upon their own land and in refusing the abuse and colonization by any other nations whom they never have the right over the land. This also approves of the rise of nationality and identity sentiments which bounds peoples to their specific place of origin. In this regard, John McLeod (2010, p.89) states that, "Nations stimulate the people's sense that they are the rightful occupants and owners of a specific landscape." Even when Anowa tells us about her grandmother's travels to other countries, however there where, "the great palaces she had been to and the wonderful things she had seen. Of the sea that is bigger than any river and boils without being hot. Of huge houses rising to touch the skies, houses whose foundations are wider than the biggest roads [she] had ever seen. They contained more rooms than were in all the homes [she] knew put together." (Aido 2004, p. 104) Nevertheless, she still felt alienated and belonged to the place because she was strange in the land itself.

The importance of place as a characteristic and a feature in postcolonialism literary texts makes the writers want to say it is not simply just to be described in terms of plot functionality, but it is shown as a place that grabs the attachment of its people. Hence, place in the postcolonialism literature has a special value and importance as it goes to the extent of representing and determining the identity of a nation. Furthermore, place constitutes an all-encompassing concept to, "demonstrate the very complex interaction of language, history and environment in the experience of colonized peoples and the importance of space and location in the process of identity formation." (Ashcroft et al., 1998, p. 177)

\section{LAND AS THE SOURCES OF BEING AND LIFE}

Aido has given a very great role to the character of land as she glorified and praised it highly to reach to the level of gods, "...Other villages produces great men, men of wealth, men of name." (Aidoo, 1987, p. 123) She literary depicts place as the responsible source of either the gifting of people with good things or torturing, or even cursing them, depending on how its people appreciate its abundant sources and generosity. She believes that place can be angry upon its people like gods. Its anger may lead to severe punishment. Towards the end of the play and right after the death of Kofi Ako and his wife, Anowa, the Old women expresses her grievances for the loss and she began complaining, "Why should this befall us? What tabooed food have we eaten? What unholy ground have we trodden?" (Aidoo, 1987, p. 123)

In Anowa, another point can be argued that when the characters were driven away from their original places, it is not due to the expulsion of the land in itself, but due to the man-made bad social and political actions. The man itself is behind its misfortunes, "Perhaps, perhaps, perhaps. And yet, no one goes mad in emptiness, unless he has the disease already in his head from the womb. No. It is men who make men mad. Who knows if Anowa would have been a better woman, better person if we had not been what we are?" (Aidoo, 2004, p. 124) it is not land to be blamed for the miseries of people, but people themselves are behind their own miseries and miseries of their citizens. Even after the expelling, the bad circumstances continue to prevail and when opportunity comes forth for Anowa to come back, "she refused to come back here to Yebi, to our gossiping and our judgments." (Aidoo, 1987, p. 124) This gives a notion of alienation from homeland whether or not you are living in it or are away from it. This is attributed to the fact that the population did not appreciate it, and it makes you feel that you do not belong there.

Roy has presented character of land in such way that clearly indicates that land is a living creature and that people should share their experiences at every moment of their life, "insanity hovered close at hand, like an eager waiter at an expensive restaurant." (Roy, 1997, p. 100) Otherwise, when a rupture happens based on this experience sharing with the land, the living human will return back to his/her homeland and finds it as some place that is odd to his/her old experiences with the 
homeland. This new experience of after return could be described as living in nowhere or a place of vacuum. Roy gives an impression of how the physical features of Ayemenem are changing with the physical changes of the human character. However, physical growth and changes seems to be very disconnected. When Estha and Rahel were young in their adulthood, the place was described as alive and abundant. Thus, after Rahel leaves it and comes back to it at the age of thirty-one, Ayemenem was described as tired, unhappy, and an exhausted person who cannot care about his or her outside appearance, "[i]t was raining when Rahel came back to Ayemenem. Slanting silver ropes slammed into loose earth, ploughing it up like gunfire. The old house on the hill wore its steep, gabled roof pulled over its ears like low hat. The walls, streaked with moss, had grown soft, and bulged a little with dampness that seeped up from the ground. The wild, overgrown garden was full of the whisper and scurry of small lives." (Roy, 1997, p. 1)

\section{HOMELAND AS THE BEST PLACE OF THE LIFE}

In an interview with Arundhati Roy, she was asked about the reason behind choosing Ayemenem as the setting for her novel. The answer was that, "[Ayemenem] was the only place in the world where religions coincide, there's Christianity, Hinduism, Marxism, and islam and they live together...I was aware of the different cultures when I was growing up and I'm still aware of them now. When you see all the competing beliefs against the same background, you realize how they all wear each other..." (Alexandru, 2015, p. 195) In both texts, TGST and Anowa, almost the main characters run away or were driven to exile from their original places each for a reason. In Anowa, despite the resistance of her family, Anowa ran away from home with her husband to escape the restriction of people of her own homeland in order to marry the man of her choice. She is in a hope of getting better life believing that her own choice of marriage will bring her changes and she can achieve her dreams. An interesting gesture in the plot is that no matter how Anowa refuses to return back to her original place, she was brought back after her death with her husband's corpse, "Osam and Badua have gone with the others to bring the two bodies home to Yebi. Ow, if there is life after death, Anowa's spirit will certainly have something to say about that!" (Aidoo, 2004, p. 124) This could thematically mean that when human being grew up on a land of his or her ancestors, s/he is already embodied with the broad concept of land (identity) and this makes her/his search of a better place to be in vain.

Thus, she came back without achieving her dreams of emancipation, independence, happiness, and freedom away from her homeland. It can be argued that at certain points, people should return back to their origin which is their home country where the real happiness falls. If people faced bad life and miseries in their own homeland, it is the people themselves that should be blamed. Also, they should work to change themselves and not the land. In support of the above idea, the Old man was blaming the people, but praising the place, "This is the type of happening out of which we get stories and legends. Yebi, I wish you due', due', due'. May all the powers that be condole with you. Kofi Ako shoots himself and Anowa drowns herself! This is too much." (Aidoo, 1987, p. 123) Therefore, returning the corpses back to the village emphasizes the idea of nationality and belonging to specific piece of land. As stated in the above mentioned lines and where ever people go and how far they run away from their original place, at the end, they should return to it at certain point. Where ever people migrate to, they cannot be a real part of the new place and they should return to their original place for breathing their final peace as McLeod states, 'although migrants may pass through the political borders of nations, crossing their frontiers and gaining entrance to new places, such 'norms and limits' can be used to exclude migrants from being accommodated inside the imaginative borders of the nation.' (McLeod, 2010: 244)

Roy's characters in TGST run away from Ayemenem in a hope of finding better future in the outside world or run away because of their problems and miseries. None of them could achieve better life or rather the life that they intended to live outside their home town, "And now, twenty-three years later, [the] father had re-Returned Estha. He had sent him back to Ayemenem with a suitcase and a letter." (Roy, 1997, p. 7) The characters search for better life did not succeed and end up with situations which are worse than their home life. They return back to their original place and this refers to the theme which reflects the sense of identity and attachment to the original homelands. Even during those times when a character tries to fix his or her unsuccessful past by leaving it behind in their place of origin, the person ends up with even more problem. For example, as Ammu, in her new place, fights her husband who tries to use her as a part of a deal with his manager to keep his job, she finds no other place to go to but her parents original place, Ayemenem, "For her she knew that there would be no more chances. There was only Ayemenem now." (Roy, 1997, p. 43)

However, both writers bring their story toward the end by returning the characters to their homeland after spending years in the outside world. It reflects the idea of people's attachments and affiliation to their original places and their sense of identity with it. Home is the important feature of Roy's TGST and Aidoo's Anowa in which it shapes a big part of their works and plays a great role in the story world just like any other main living characters. John McLeod (2010, p. 242) in his book Beginning Postcolonialism about the importance of home argues that, "[t]he concept of 'home' often performs an important function in our lives. It can act as a valuable means of orientation by giving us a fixed and a reliable sense of our place in the world. It is meant to tell us where we originated from and apparently where we legitimately belong. As an idea, it stands for shelter, stability, security, and comfort (although actual experiences of home may well fail to deliver these promises. To be 'at home' is to occupy a location where we are welcome, where we can be with people that we may regard very much like ourselves, where we are not at sea but have found safe harbor."

\section{CONCLUSION}

It can be concluded that colonization expeditions of European countries had left a great aftermath and created an important historical effects over the colonized nations. The colonization expeditions left effects on different aspects of life and it imposed itself to be studied as a special field in English Literature. Thus, many writers among the colonized nations have shaped the period with its issues and problems via their literary work.

Among the well-known writers who devoted their writing toward discussing the major issues of their post-colonial society are the Ghanaian writer, Ama Ata Aidoo, through her play, Anowa; and the Indian writer, Arundhati Roy, through her first novel TGST which is the booker prize winner. These 
two writers have very intellectually brought up the most important issues for their people and the society such as the importance of land. Both writers have raised the issue and mirrored it as a very serious part of their writing. In addition, they have brought the reality to the surface that land is not a matter of a specific spot on the earth, but it is rather the identity and the cause behind the existences of a nation. The other more important part is that they are both suggesting some very important solutions. They present ideas which help their people to move forward for reform and change which can result in freedom and equality, plus strengthening national identity and patriotic spirit which reduces the danger in any kind of the future colonization. Hence, the issue of place and displacement is a main feature in the postcolonial literature and it holds the concern about the identity and self-assurance.

\section{REFERENCES}

8.1 Primary Texts:

Roy, A. 1997, The God of Small Things, London: Harper Perennial

Aidoo, A, A, 1987, The Dilemma of a Ghost and Anowa, Harlow: Longman

8.2 Secondary Texts:
Alexandru, M 2015, Performance and Performativity in Contemporary Indian Fiction in English, Brill | Rodopi

Ashcroft, B., et al. 1998, Key Concept in Post-Colonial Studies, London: Routledge

Ashcroft, B., et al. 1989, The Empire Writes Back. New York: Routledge.

Azodo, A. U. and Wilentz, G. (eds.) 1999, Emerging Perspective on Ama Ata Aidoo, Trenton, NJ: Africa World Press

Balvannanadhan, A. 2007, Arundhati Roy's The God of Small Things: A study in Multiple Narratives, New Delhi: Prestige Books

Eke, M. N. 1999, "Diasporic Ruptures and (Re)membering History: Africa as Home and Exile in Anowa and The Delimma of a Ghost" in Azodo, A. U. and Wilentz, G. (eds.) Emerging Perspective on Ama Ata Aidoo, Trenton, NJ : Africa World Press Pp. 61-78

Knepper, W. 2011, Postcolonial Literature, London: York Press

McLeod, J. 2010, Beginning Postcolonialism, Manchester: Manchester University Press

Tickell, A. 2007, Arundhati Roy's The God of Small Things, London: Routledge. 


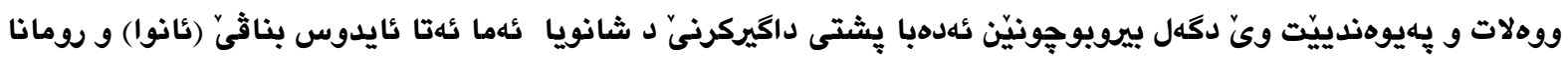

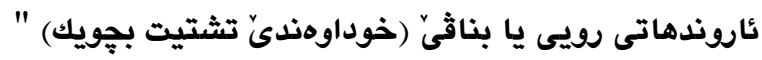

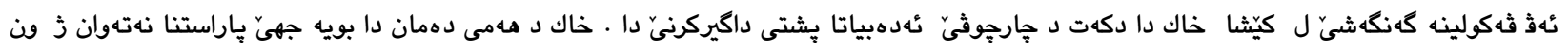

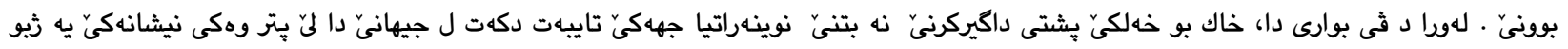

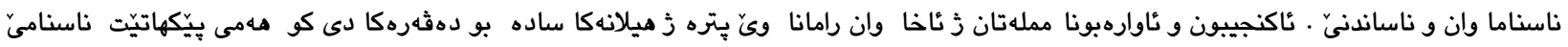

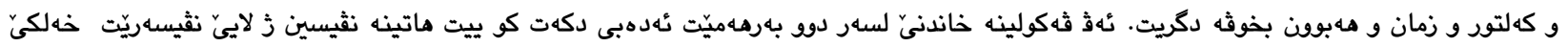

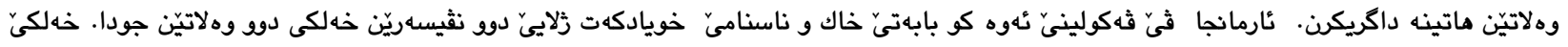

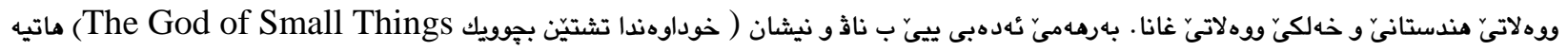

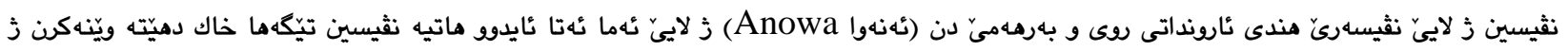

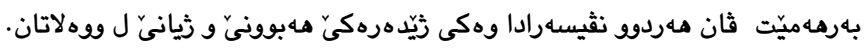

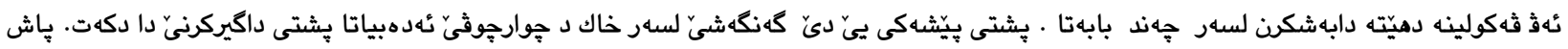

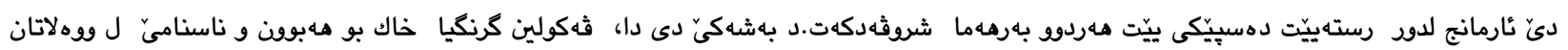

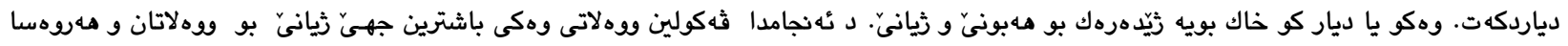

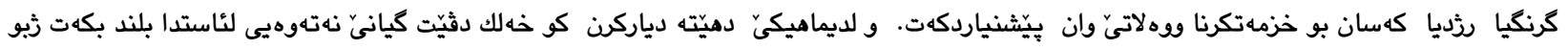

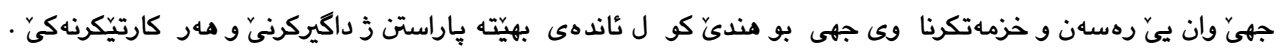

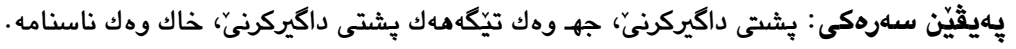

الارض وعلاقتها بمنظورات ادب بعد الاستعمار في مسرحية "انوا" لأما أتا أيدو ورواية "أله الأشياء الصغيرة" لأروندهاتي روي

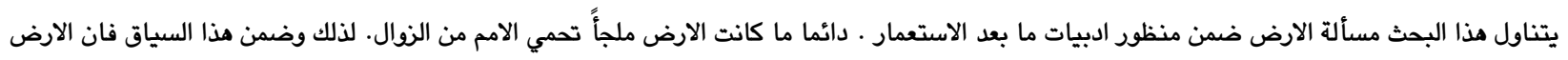

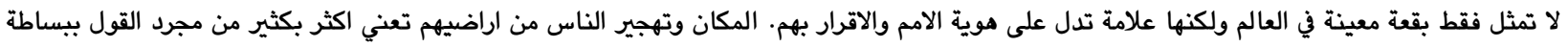

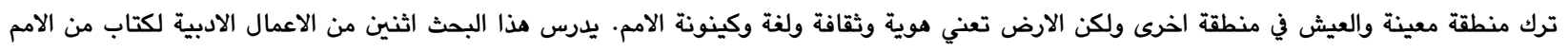

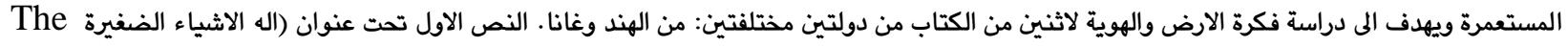

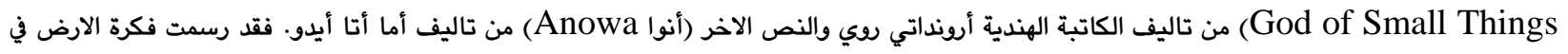
اعمال هاتين الكاتبتين كمصدر الوجود ويقاء الامم.

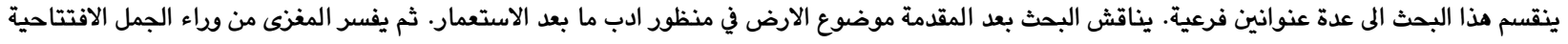

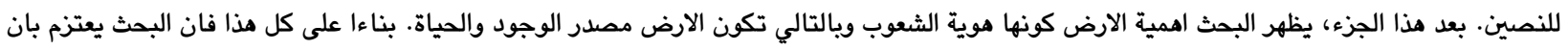

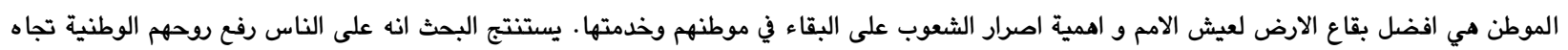
مناطقهم الاصلية وخدمتها من اجل تفادي حملات استعمارية مستقبلية ومنع حدوث عواقبها. الكلمات الدالة: مابعد الأستعمار، المكان كمفهوم مابعد الاستعمار، الأرض كهوية. 